\title{
Intra-rater reliability of rehabilitative ultrasound imaging of the cervical multifidus muscle in healthy subjects
}

\author{
Beata Czechowska ${ }^{1}$, Katarzyna Gilbov ${ }^{1}$, Marcin Świątczak ${ }^{\mathbf{2}}$ \\ ${ }^{1}$ Department of Methodology of Teaching Movement, Medical University of Lodz, Poland \\ 2Department of Ortopaedic and Posttraumatic Rehabilitation, Medical University of Lodz, Poland \\ Correspondence to: Beata Czechowska, beata.czechowska96@gmail.com \\ DOI: https://doi.org/10.5114/for.2021.106948
}

Received: 25.02.2021 Reviewed: 07.03.2021 Accepted: 07.03.2021

\begin{abstract}
Background: The multifidus muscle is a deep muscle and the main stabiliser of the spine. Abnormal activity and morphology of this muscle can provoke cervical spinal pain. One way to assess the morphology of deep stabilising muscles is ultrasonography. There is limited evidence on the reliability of measuring the multifidus muscle in the cervical region of the spine using rehabilitative ultrasound imaging (RUSI).
\end{abstract}

Aims: This study aimed to evaluate the reliability of measuring the cross-sectional area, surface area, and circumference of the multifidus muscle in the cervical region of the spine

Material and methods: The study involved 10 healthy subjects, including 7 women and 3 men, aged 23-62 years. The cross-sectional area, circumference, and surface area of the multifidus muscle in the cervical section of the spine were measured in the subjects using RUSI. The intraclass correlation coefficient (ICC) was used for each measurement (3.1-3.3) as recommended index for the intra-rater reliability assessment.

Results: Taking measurements twice, with a 15-minute interval between them, increased the reliability of measurements of the cross-sectio- nal area, surface area, and circumference of the multifidus muscle in the cervical section of the spine to ICC $>0.9$, which indicates excellent reliability. The mean of the three measurements decreased the ICC value to $0.8-0.9$, showing good reliability of the measurements. The ICC 3.3 values for measurements of the area and circumference of the multifidus muscle in the cervical region of the spine performed after seven days were lower, in the range of 0.48-0.55, which suggests questionable reliability of measurements. The value of ICC 3.3 of the cross-sectional area also decreased, although it remained in the upper limit (0.85), demonstrating good reliability of the measurement.

Conclusions: The RUSI is a reliable tool for assessing the morphology of the multifidus muscle in the cervical spine region.

\section{Key words}

reliability, ultrasonography, cervical multifidus, RUSI 


\section{Introduction}

Pain is defined as an unpleasant experience with a sensory and emotional character [1]. Spinal pain is one of the most common musculoskeletal dysfunctions. Approximately $80 \%$ of the population complains of back pain at least once in their lifetime [2]. The lumbar region of the spine is the most commonly affected [2]. However, statistical data indicate that the prevalence of cervical spine pain has been increasing, and as much as $30-50 \%$ of the population may suffer from this condition [2, 3]. This problem is also a serious health, social, and economic burden.

The most common causes of pain in the cervical spine include degenerative changes and intervertebral disc dysfunction [3, 4]. These can occur due to an asymmetry in the morphology and activity of the deep stability muscles, particularly the multifidus muscle $[5,6]$. Other causes include trauma and its consequences, osteoporosis, neoplastic lesions, inflammation, and connective tissue defects [7]. A sedentary lifestyle, lack of physical activity, and excessive stress also contribute to pain $[8,9]$. The prolonged staying in one position contributes to damage to the intervertebral disc, which accelerates the degenerative processes of vertebral bodies [10-12]. The influence of the emotional state on the entire human organism, including pain complaints, is also being increasingly emphasised. Decreased mood and general fatigue can also lead to the intensification of pain symptoms [13-15].

The multifidus muscle is classified as a deep muscle and is the main stabiliser of the spine. Studies on the thickness of the multifidus muscle in the cervical region in patients with cervical disc herniation and radiculopathy have revealed its asymmetry $[5,6]$. This confirms that abnormal activity and morphology of the multifidus muscle in the cervical spine affect cervical pain occurrence $[5,6]$.

The diagnostic process is an essential component in the treatment of cervical spine pain. Ultrasonography is one way to evaluate the morphology of deep stabilising muscles [16-18]. It is a reliable tool for evaluating the anterolateral abdominal wall muscles [19], as well as the lumbar multifidus muscle [16]. Ultrasound also allows the implementation of visual feedback to provide knowledge and understand a motor task's performance on deep muscles, including the transversus abdominis and multifidus muscles [16, 17].

To date, few studies have reported on the reliability of measuring the multifidus muscle in the cervical spine using rehabilitative ultrasound imaging (RUSI). Ultrasound is beginning to be used in diagnosing the musculoskeletal system, especially in individuals suffering from non-specific cervical spine pain syndromes. However, first of all, it is necessary to determine its reliability.

\section{Aims}

This study aimed to evaluate the reliability of the RUSI method for physiotherapy purposes and analyse this reliability by a single investigator at different intervals. The cross-sectional area, surface area, and circumference of the multifidus muscle in the cervical spine region were measured.

\section{Material and methods}

\section{Ethical considerations}

Participation in the study was voluntary. The subjects were provided with information regarding the course of the study and gave their written consent to participate in the study. Approval for the study was obtained from the Bioethics Committee with the number RNN/69/18/KE dated February 15, 2018.

\section{Study participants}

The study was conducted among the population of Lodz in Poland. There were 10 participants in the study, including 3 men and 7 women. The criteria for inclusion in the study group were written consent to participate in the study, no cervical spine pain, and no injuries to the head, neck, 
or shoulder girdle. The exclusion criteria were cervical spine pain, head, neck, and shoulder girdle injuries, and a lack of written informed consent.

\section{Measurements}

This study evaluates the intra-rater reliability of the RUSI method for the multifidus muscle in the cervical spine using an ultrasound device (Honda Electronics Co., Ltd. Japan, HS-2200 W, frequency $8.5 \mathrm{MHz}$ and B-mode). The circumference, surface area, and cross-sectional area of the multifidus muscle in the multifidus muscle on the right side of the cervical region of the spine.

The head of the ultrasound device was placed transversely at the level of the $\mathrm{C} 4$ vertebra. To determine the examination point, knowledge of palpation anatomy was used, and the level of the $\mathrm{C} 4$ vertebra was marked to measure the appropriate location in all subjects. During the examination, the patient was in a sitting position, with the feet resting on the floor at right angles to the lower limb joints and the upper limbs placed freely along the trunk to avoid displacement and ensure a stable position for the patient. The patient's head was positioned in the maximum possible flexion to obtain proper access to the multifidus muscle during the examination and provide a comfortable and stable position for both the subject and the examiner. The cross-sectional area of the multifidus muscle was measured at its widest point by running a perpendicular line between the upper edge of the lower fascia and the lower edge of the upper fascia of the multifidus muscle (visible as two hyperechogenic bright lines) (Fig. 1). The circumference and surface area measurements were taken at the border between the muscle tissue and the fascia of the multifidus muscle. The measurements were taken on the right side. The examiner performed three sets of measurements at 1 -minute intervals.

\section{Procedures}

The study consisted of three stages. First, the cross-sectional area, surface area, and circumference of the multifidus muscle were measured. After 15 minutes, these measurements were

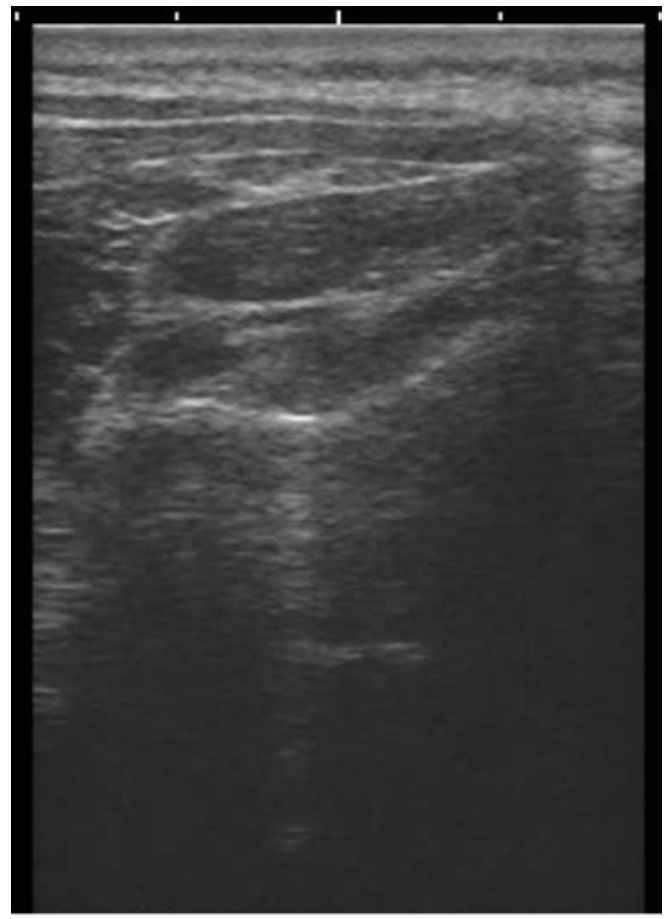

Figure 1. Ultrasonographic imaging of the multifidus muscle in the cervical spine. 
repeated, which constituted the second stage of the study. In the third stage of the study, the above-mentioned measurements were repeated after seven days. In each phase, the measurements were taken three times (Fig. 2).

\section{Researcher 1}

3 sets of measurements with one minute interval between measurements
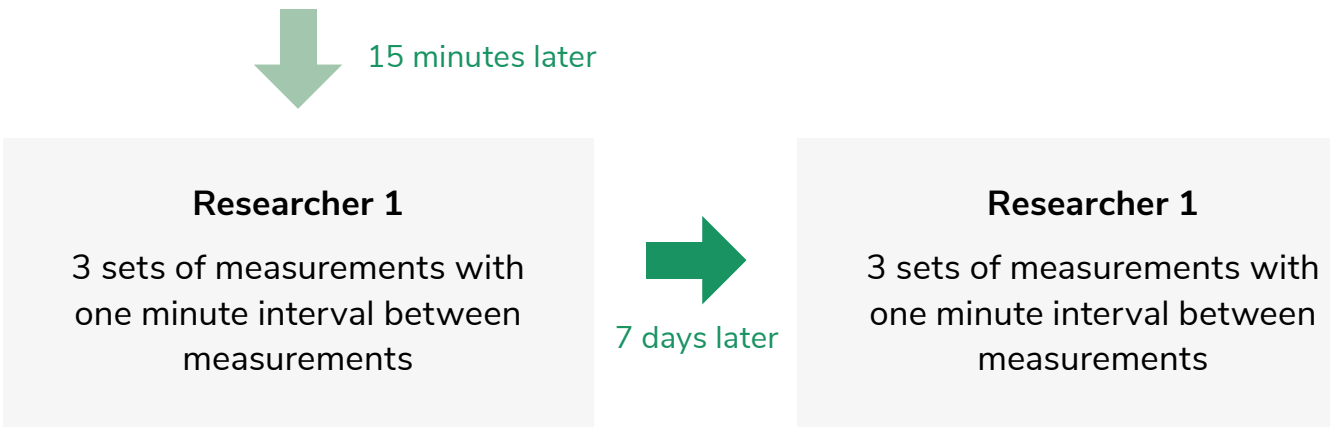

Figure 2. A diagram of the study developed by the authors.

\section{Statistical analysis}

The results are presented as mean values and standard deviations $( \pm \mathrm{SD})$. The intraclass correlation coefficient (ICC) was calculated based on the first measurement taken by Researcher 1 (ICC 3.1), the mean of the second measurement (ICC 3.2), and the mean of all three measurements (ICC 3.3). Using the ICC, the reliability of the measurements was calculated. ICC is a coefficient ranging from 0.00 to 1.00. Values above 0.9 indicate excellent reliability, between 0.9 and 0.8 good reliability, between 0.8 and 0.7 acceptable reliability, and below 0.7 questionable reliability [20, 21]. The smallest detectable difference (SDD) was also calculated for all tested parameters: $1.96 \times$ p2 $\times$ standard error of measurement (SEM). The SEM was calculated as the standard deviation of the measurements divided by $\sqrt{1}-$ ICC. The results were analysed using Statistica 10 and the Microsoft Excel 2016 package. The relationship between the data obtained was determined via descriptive statistics.

\section{Results}

The study included 10 subjects (7 women and 3 men) between 23 and 62 years of age. The detailed characteristics of the study group are presented in Table 1. 
Table 1. The characteristics of the study group (mean $\pm S D$ ).

\begin{tabular}{|c|c|}
\hline Characteristics & Participants (n=10) \\
\hline Sex $(\mathrm{F} / \mathrm{M})$ & $7 / 3$ \\
\hline Age [years] & $62.0 \pm 35.6$ \\
\hline Body mass $[\mathrm{kg}]$ & 73.7 \\
\hline Body height $[\mathrm{cm}]$ & 169.8 \\
\hline BMI $\left[\mathrm{kg} / \mathrm{m}^{2}\right]$ & 25.41 \\
\hline
\end{tabular}

Legend: F - female; M - male; BMI - body mass index; n - number of participants; SD - standard deviation.

Initially, the values of the following indices were determined: ICC, SEM, and SDD for the first measurement of the multifidus muscle in the cervical spine in relation to the second measurement performed after 15 minutes (Table 2).

The ICC 3.1 values for the measurements of the cross-sectional area and the circumference of the multifidus muscle in the cervical region of the spine indicate acceptable reliability. On the other hand, the surface area was measured with excellent reliability (ICC $=0.93)$. Performing the measurement twice increased its reliability in relation to the first measurement of the cross-sectional area, surface area, and circumference of the multifidus muscle in the cervical section of the spine to ICC $>0.9$, indicating excellent reliability. The mean of the three measurements decreased the ICC value, which nevertheless remained within the range of $0.8-0.9$, representing good reliability (Table 2).

Table 2. Estimation of intra-rater reliability (measurement 1 vs measurement 2).

\begin{tabular}{|c|c|c|c|c|c|c|c|c|c|c|c|c|}
\hline \multirow{3}{*}{ Parameter } & \multicolumn{6}{|c|}{ Measurement 1} & \multicolumn{6}{|c|}{ Measurement 2} \\
\hline & \multicolumn{3}{|c|}{$\mathrm{ICC}^{1}$} & \multicolumn{3}{|c|}{ SEM } & \multicolumn{3}{|c|}{ SDD } & \multicolumn{3}{|c|}{ Bias $^{2}$} \\
\hline & 3.1 & 3.2 & 3.3 & 1 & 2 & 3 & 1 & 2 & 3 & 1 & 2 & 3 \\
\hline $\begin{array}{l}\text { Cross-sectional } \\
\text { area }[\mathrm{mm}]\end{array}$ & 0.78 & 0.91 & 0.89 & 0.26 & 0.18 & 0.21 & 0.72 & 0.50 & 0.58 & 0.25 & 0.25 & 0.29 \\
\hline $\begin{array}{c}\text { Surface area } \\
{\left[\mathrm{mm}^{2}\right]}\end{array}$ & 0.93 & 0.94 & 0.89 & 8.84 & 7.78 & 10.9 & 24.5 & 21.6 & 30.2 & 7.50 & -0.15 & 1.37 \\
\hline $\begin{array}{c}\text { Circumference } \\
{[\mathrm{mm}]}\end{array}$ & 0.78 & 0.91 & 0.85 & 4.02 & 2.30 & 3.20 & 11.1 & 6.67 & 8.87 & 2.61 & 0.14 & 0.33 \\
\hline
\end{tabular}

Legend: 'ICC - intraclass correlation coefficient; SEM - standard error of measurement; SDD - smallest detectable difference; ${ }^{2}$ Bland-Altman Test; 1 - for a single measurement; 2 - for the mean value from two measurements; 3 - for the mean value from three measurements. 
In order to assess the reliability of the measurements presented in this study, the ICC, SEM, and SDD values were determined for the first measurements of the multifidus muscle in the cervical spine in relation to those performed after seven days (Table 3).

The ICC 3.3 values for the measurements of the surface area and circumference of the multifidus muscle in the cervical region of the spine were lower, ranging between 0.48 and 0.55 , indicating questionable reliability of the measurements. While the reliability of the measurement of the cross-sectional area also decreased, the value of ICC 3.3 remained within the upper limit of 0.85 , a value suggesting good reliability (Table 3).

Table 3. Estimation of intra-rater reliability (measurement 1 vs measurement 3).

\begin{tabular}{|c|c|c|c|c|c|c|c|c|c|c|c|c|}
\hline \multirow{3}{*}{ Parameter } & \multicolumn{6}{|c|}{ Measurement 1} & \multicolumn{6}{|c|}{ Measurement 3} \\
\hline & \multicolumn{3}{|c|}{$\mathrm{ICC}^{1}$} & \multicolumn{3}{|c|}{ SEM } & \multicolumn{3}{|c|}{ SDD } & \multicolumn{3}{|c|}{ Bias $^{2}$} \\
\hline & 3.1 & 3.2 & 3.3 & 1 & 2 & 3 & 1 & 2 & 3 & 1 & 2 & 3 \\
\hline $\begin{array}{l}\text { Cross-sectional } \\
\text { area }[\mathrm{mm}]\end{array}$ & 0.83 & 0.86 & 0.85 & 0.23 & 0.22 & 0.24 & 0.63 & 0.62 & 0.67 & $0.29^{3}$ & $0.31^{3}$ & $0.33^{3}$ \\
\hline $\begin{array}{l}\text { Surface area } \\
{\left[\mathrm{mm}^{2}\right]}\end{array}$ & 0.51 & 0.63 & 0.55 & 22.2 & 17.9 & 19.2 & 61.6 & 49.7 & 53.1 & 2.50 & 3.25 & 3.73 \\
\hline $\begin{array}{c}\text { Circumference } \\
{[\mathrm{mm}]}\end{array}$ & 0.44 & 0.63 & 0.48 & 6.68 & 4.93 & 5.60 & 18.5 & 13.7 & 15.5 & $6.82^{3}$ & $7.11^{3}$ & $6.99^{3}$ \\
\hline
\end{tabular}

Legend: ${ }^{1} \mathrm{ICC}$ - intraclass correlation coefficient; SEM - standard error of measurement; SDD - smallest detectable difference; ${ }^{2}$ Bland-Altman Test; ${ }^{3}$ Systematic error (SE) - the line of equality does not fall within the $95 \%$ confidence interval (CI); 1 - for a single measurement; 2 - for the mean value from two measurements; 3 - for the mean value from three measurements.

\section{Discussion}

This study aimed to evaluate the reliability of the RUSI method used as a diagnostic and therapeutic tool in physiotherapy to examine the multifidus muscle of the cervical spine. The results showed the importance of the number of measurements taken. Hence, the authors concluded that at least two measurements should be conducted (with a 1-minute interval between them) to reduce the SDD value. This approach is appropriate if the results obtained demonstrate good or excellent reliability for all measurements of the multifidus muscle.
In the present study, the ICC 3.3 of the first measurement of the cross-sectional area, surface area, and circumference of the multifidus muscle in the cervical spine in relation to the measurement made after 15 minutes was 0.80 , indicating good measurement reliability. This result is consistent with those of other studies that evaluated the reliability of the RUSI [22-25].

The literature on the thickness of the abdominal muscle showed similar reliability results. One study yielded an ICC 3.3 coefficient of 0.95 for all measurements, indicating very good reliability 
[26]. Researchers have also focused on assessing reliability in different age groups, including children, adolescents, and adults. In adults, the ICC 3.3 remained at or above 0.90 . The present study and reference [26] both indicate very good reliability of RUSI, and the values of the ICC 3.3 are similar. Therefore, there is no relationship between the subjects' age and measurement reliability [23, 27].

Measurements of the multifidus muscle in the cervical spine were performed three times, although in the second measurement, the ICC 3.2 was already above 0.90 . Other authors have also pointed out that, with only two measurements, the reliability of the final result can be established [23]. Thus, it seems unnecessary to perform triple measurements, as recommended by some authors [26], which saves time for both the patient and the examiner. The mean values obtained from the three measurements prove higher reliability. It is worth noting that the researcher's experience in RUSI method is significant for the obtained results, which in the case of this study was modest. Despite this fact, the results were satisfactory.

RUSI is also used to assess real-time movement, which allows for feedback to both the patient and therapist. This is of great importance when examining anatomical structures that are difficult to examine visually and by palpation (such as the multifidus muscle in the cervical spine). There is fair scientific evidence that supports the reliability of RUSI in assessing the activity, function, and morphology of the transversus abdominis and the lumbar multifidus muscles [19, 21, 26, 29-36]. However, there are few studies concerning the multifidus muscle in the cervical spine. On the other hand, its role in pain in this region has been confirmed $[5,6]$. The increasing prevalence of cervical pain and the need for appropriate diagnostics demonstrate the importance of studies on the multifidus muscle in the cervical spine. Therefore, further research on the multifidus muscle is necessary to provide reliable results that will increase the diagnostic relevance of RUSI.
The present study assessed the reliability of measurements taken by only one investigator (intra-rater); therefore, future research projects should assess the degree of reliability based on results obtained by two investigators (inter-rater) at different time intervals and using different ultrasound equipment $[37,38]$.

\section{Study limitations}

The limitations of the study were the relatively small number of subjects, the age range, and the inexperience of the researcher. Therefore, further research on the reliability of the RUSI is needed to make it a more common method in physiotherapy practice.

\section{Conclusions}

The RUSI is a reliable tool to assess the morphology of the multifidus muscle in the region of the cervical spine. At least two measurements should be conducted including a 1-minute interval to minimise the measurement error by reducing the SDD values. This approach is appropriate if the results obtained demonstrate good or excellent reliability for all measurements of the multifidus muscle. 


\section{References}

1. Loeser JD. The Kyoto protocol of IASP Basic Pain Terminology. Pain 2008; 137: 473-477.

2. Matuszewska W, Tomczak H. Ocena wpływu kompleksowej fizjoterapii na poziom bólu

3. w odcinku szyjnym kręgosłupa. Acta Balneol. 2011; 53 (2): 124-132.

4. Tomik B. Leczenie zespołów bólowych kręgosłupa. Terapia 2003; 11 (4): 39-42.

5. Istrati J. Przewlekły zespół bólowy kręgosłupa szyjnego - postępowanie według medycyny opartej na faktach. Ból 2011; 12 (4): 15-18.

6. Chae SH, Lee SJ, Kim MS, Kim TU, Hyun JK. Cervical Multifidus Muscle Atrophy in Patients with Unilateral Cervical Radiculopathy. Ann Rehabil Med. 2010; 34 (6): 743-751.

7. Lee JP, Wang CL, Shau YW, Wang SF. Measurement of cervical multifidus contraction pattern with ultrasound imaging. J Electromyogr Kinesiol. 2009; 19 (3): 391-397.

8. Dobrogowski J, Dutka J. Zespoły bólowe narządu ruchu. Terapia 2004; 10 (157): 36-41.

9. Guzy G, Szpitalak M, Frańczuk B, Ridan T. Relationships among psychological factors and selected variables among patients with chronic, cervical derangement syndrome. Med Sport. 2013; 29 (3): 163-173.

10. Klimaszewska K, Krajewska-Kułak E, Kondzior D, Kowalczuk K, Jankowiak B. Quality of life in patients with lumbar spine pain syndromes. Probl Pielęg. 2011; 19: 47-54.

11. Cabak A, Wasilewski L, Zdrodowska A, Tomaszewski P. Pain control in patients with chronic back pain syndrome. Ortop Traumatol Rehabil. 2011;13 (4): 361-368.

12. Żytkowski A, Sosnowiski S, Wrodycka B. Etiopatogeneza choroby zwyrodnieniowej kregosłupa [Spondylarthrosis etiopathogenesis]. Pol Merkur Lekarski. 2006; 21 (125): 498-501.

13. Garczyński W, Paszkiewicz A, Żukow W. Działanie analgetyczne krioterapii miejscowej i magnetoterapii w chorobie zwyrodnieniowej stawów lędźwiowego odcinka kręgosłupa. In: Czerwińska-Pawluk I, Żukow W, editors. Humanistyczny wymiar fizjoterapii, rehabilitacji, pielęgniarstwa, zdrowia publicznego, turystyki i rekreacji. Radom: Radomska Szkoła Wyższa; 2010; 31-43.

14. Walden-Gałuszko K, Majkowicz M, Janiszewska J, Jankowska B. Uwarunkowania psychologiczne percepcji bólu przewlekłego. Badanie porównawcze chorych z różnym patomechanizmem bólu. Psychoonkologia 2008; 12 (1): 1-6.

15. Stodolny J. Choroba przeciążeniowa kręgosłupa. Epidemia naszych czasów. ZL Natura; Kielce 1999.

16. Rakowski A. Kręgosłup w stresie. Jak usunąć ból i jego przyczyny. Gdańsk: GWP; 2008.

17. Whittaker JL, Teyhen DS, Elliott JM, Cook K, Langevin HM, Dahl HH, Stokes M. Rehabilitative ultrasound imaging: understanding the technology and its applications. J Orthop Sports Phys Ther. 2007; 37 (8): 434-449.

18. Henry SM, Westervelt KC. The use of real-time ultrasound feedback in teaching abdominal hollowing exercises to healthy subjects. J Orthop Sports Phys Ther. 2005; 35: 338-345.

19. Kiesel KB, Uhl TL, Underwood FB, Rodd DW, Nitz AJ. Measurement of lumbar multifidus muscle contraction with rehabilitative ultrasound imaging. Man Ther. 2007; 12: 161-166.

20. Michalak K, Czechowska B, Wolny T, Motylewski S, Poziomska-Piątkowska E. The use of Rehabilitative Ultrasound Imaging (RUSI) and sonofeedback in the assessment of the activity of transversus abdominis muscle. Fizjoter Pol. 2017; 17 (4): 50-61.

21. George D, Mallery P. SPSS for Windows Step by Step: A Simple Guide and Reference. Allyn \& Bacon, Boston, MA 1995.

22. Wolny T, Linek P. Reliability of two-point discrimination test in carpal tunnel syndrome patients. Physiother Theory Pract. 2019; 35 (4): 348-354.

23. McMeeken JM, Beith ID, Newham DJ, Milligan P, Critchley DJ. The relationship between EMG and change in thickness of transversus abdominis. ClinBiomech (Bristol, Avon). 2004;19 (4): 337-342.

24. Koppenhaver SL, Hebert JJ, Fritz JM, Parent EC, Teyhen DS, Magel JS. Reliability of rehabilitative ultrasound imaging of the transversus abdominis and lumbar multifidus muscles. Arch Phys Med Rehabil. 2009; 90: 87-94. 
25. Teyhen DS, Williamson JN, Carlson NH, Suttles ST, O'Laughlin SJ, Whittaker JL, et al. Ultrasound characteristics of the deep abdominal muscles during the active straight leg raise test. Arch Phys Med Rehabil. 2009; 90 (5): 761-767.

26. Linek P, Saulicz E, Wolny T, Myśliwiec A. Reliability of B-mode sonography of the abdominal muscles in healthy adolescents in different body positions. J Ultrasound Med. 2014; 33 (6): 1049-1056.

27. Linek P, Saulicz E, Wolny T, Myśliwiec A. Reliability of B-mode ultrasound imaging of the lateral abdominal muscles in healthy children during the active straight leg raise test. Physiother Health Act. 2014; 22 (1): 1-7.

28. Bunce SM Hough AD, Moore AP. Measurement of abdominal muscle thickness using M-mode ultrasound imaging during functional activities. Man Ther. 2004; 9: 41-44.

29. Misuri G, Colagrande S, Gorini M, Iandelli I, Mancini $M$, Duranti R, et al. In vivo ultrasound assessment of respiratory function of abdominal muscles in normal subjects. Eur Respir J. 1997; 10 (12): 28612867.

30. Dietz HP Wilson PD, Clarke B. The use of perineal ultrasound to quantify levator activity and teach pelvic floor muscle exercises. Int Urogynecol J Pelvic Floor. 2001; 12 (3): 166-169.

31. Linek P, Saulicz E, Wolny T, Myśliwiec A. Body Mass Normalization for Ultrasound Measurements of Adolescent Lateral Abdominal Muscle Thickness. J Ultrasound Med. 201736 (4): 775-782.

32. Wolny T, Linek P, Michalski P. Inter-rater reliability of two-pointdiscrimination in acute stroke patients. NeuroRehabilitation 2017; 41 (1): 127-134.

33. Linek P, Sikora D, Wolny T, Saulicz E. Reliability and number of trials of Y Balance Test in adolescent athletes. Musculoskelet Sci Pract. 2017; 31: 72-75.

34. Taghipour M, Mohseni-Bandpei MA, Abdollahi I, Rajabzdach F, Naghdi N, Pourahmadi MR. Reliability of B-mode ultrasonography to measure lumbar multifidus muscle dimensions in patients with unilateral lumbar disc herniation. J Bodyw Mov Ther. 2020; 24 (2): 153-157.

35. Kandel M, Cattrysse E, De Maeseneer M, Lenchik L, Paantjens M, Leeuw M. Inter-rater reliability of an ultrasound protocol to evaluate the anterolate- ral ligament of the knee. J Ultrason. 2019; 19 (78): 181-186.

36. Hosseinifar M, Akbari A, Ghiasi F. Intra-Rater Reliability of Rehabilitative Ultrasound Imaging for Multifidus Muscles Thickness and Cross Section Area in Healthy Subjects. Glob J Health Sci. 2015; 7 (6): 354-361.

37. Hahna J, Hab HG, Leec HJ, Lima S, Lee WH. The reliability of dual rehabilitative ultrasound imaging measurements for muscle co-activation. Phys Ther Rehabil Sci. 2017; 6 (3): 152-157.

38. Baño-Aledo ME, Martínez-Payá JJ, Ríos-Díaz J, Mejías-Suárez S, Serrano-Carmona S, de Groot-Ferrando A. Ultrasound measures of tendon thickness: Intra-rater, Inter-rater and Inter-machine reliability. Muscles Ligaments Tendons J. 2017; 7 (1): 192-199. 